\title{
Prevalence of musculoskeletal pain and environmental health hazards among tea pluckers of Maddekanda tea estate in Balangoda Pradeshiya Saba Division, Sri Lanka
}

\author{
Uhulanage Harshani Shiromali Chandrasekara, ${ }^{1}$ Sudath Shirely Pathmasiri Warnakulasuriya, ${ }^{2}$ \\ Gnanaselvam Kisokanth ${ }^{2}$ \\ ${ }^{1}$ Divisional Hospital, Kalthota; ${ }^{2}$ Department of Clinical Nursing, Faculty of Nursing, University of Colombo, \\ Sri Lanka
}

\begin{abstract}
Background: Tea pluckers in Sri Lanka play a prominent role in supplying tea for the local and foreign demand. Long standing, bearing weight on back, repetitive hand movements, slip and falls due to walking on uneven grounds lead to various health problems among them. Thus, this study was aimed to assess the prevalence of musculoskeletal pain and environmental health hazards among tea pluckers of Maddekanda tea estate in Balangoda area, Sri Lanka.

Design and Methods: A descriptive cross-sectional study was carried out among 378 tea pluckers, recruited using simple random sampling method. Data were collected by validated, pretested interviewer administered questionnaire and descriptive and inferential statistical analyses were performed by using SPSS v20.

Results: The prevalence of musculoskeletal pain in any region of the body was $68.5 \%$ (95\% CI 63.6-73.2) among all participants and prevalence of lower back pain $43.4 \%$ (95\% CI 38.3-48.8) was high compared to other site of pain. Nearly $98.4 \%$ had experienced of leech biting during their work as a main health hazard. Participants who had experienced stress $(\mathrm{OR}=2.12,95 \% \mathrm{CI}$ : 1.119-3.764), and worked for more than 20 years $(\mathrm{OR}=2.28,95 \%$ CI: $1.37-3.81$ ) were nearly 2 times more likely to have musculoskeletal pain when compared to their counterparts.

Conclusions: Prevalence of musculoskeletal pain was high among tea pluckers and lower back region was the common site of pain. Leech bite was the other dominant health problem faced by them. Stress, duration of work and age were associated with musculoskeletal pain.
\end{abstract}

\section{Introduction}

Tea is the major agricultural export crop of Sri Lanka which was introduced to the country in 1867 by James Taylor. ${ }^{1}$ Tea has been recognized as a pleasant, safe, healthy drink and it is enjoyed every day by many people all over the world. ${ }^{2}$ Sri Lanka is the world's fourth-largest producer of tea. Sri Lankan tea estate workers play a prominent role in order to supply tea for the local and foreign demand. Most of the estate workers are female tea pluckers who are involved in picking tea leaves. According to the nature of the tea plucking job, workers are exposed to various physical, psychological and environmental health hazards. Physical hazards include long standing, bearing weight on back, repetitive hand movements, slip, strip and falls due to walking on uneven grounds by bearing weights on back lead to various health problems. With regards to environmental condition these workers are exposed to different windy, rainy and sunny weather conditions in the outfield. Psychologically they experience time pressure to complete targets, supervisor pressure and job insecurity related to various climate conditions as day labors.

According to Ilyas, ${ }^{3}$ most of the Tamil people who live in hill country are employed in the plantation sector of Sri Lanka. They live in typical houses known as line rooms with less healthy conditions. ${ }^{3}$ Their houses do not have adequate ventilation, sunlight, sanitary facilities, safe drinking water and privacy for grown up children and most of the houses are overcrowded due to increased number of family members of few generation. Further, there are serious social problems such as widespread poverty, alcoholism, domestic violence, poor housing conditions and lack of support at old age as well as under nutrition and anemia. ${ }^{4}$

Occupational health is defined as the promotion and maintenance of the highest degree of physical, mental and social wellbeing of workers in all occupations by preventing departures from health, controlling risks and the adaptation of work to people, and people to their jobs. ${ }^{5}$ Estate workers are vulnerable for various health condition and diseases due to physical, psycho social and environment factors.

Further, Park $^{6}$ stated that occupation and health are closely related, and the occupational environment of the worker cannot be separated from his domestic environment because, both are complementary to each other. And stress at workplace may disturb their domestic life just as stress at home may affect their work. ${ }^{6} \mathrm{~A}$ research studies related to workers in the tea industry revealed that musculoskeletal disorders are common in this worker as a result of occupational health hazards in the working environment. ${ }^{7}$

Significance for public health

Identified occupation related health problems such as musculoskeletal pain, stress and health hazards such as leech bite, honey bee or wasp attacks, snake bite among tea pluckers of Maddekanda tea estate in Balangoda area, need to be addressed by the relevant authorizes in order to ensure the good health and the safety of the workers. In addition, the findings of this study would further emphasize to carry out more studies in order to assess the associated factors for each occupational health problems among tea pluckers. Further, there is need for health campaign to identify undiagnosed health problems among this population. 
According to Department of Census and Statistics of Sri Lanka, Labour force Survey 2014, nearly 30\% of Sri Lankan population working in agriculture and many are at risk for work related musculoskeletal disorders. Tuzun ${ }^{8}$ stressed that musculoskeletal (MS) pain is associated with poor quality of life and reduced productivity. ${ }^{8}$ Even though large number of research studies have been carried out in other countries on physical problems related to musculoskeletal system and psychological stress related to occupation, majority had not been touched on previous experiences on biological hazards of working place among tea pluckers. In addition, there is a sparsity in reported evidence on occupational health condition among tea pluckers in Sri Lanka. Therefore, present study may contribute to the existing gap on knowledge regarding occupational health among tea pluckers. Thus, focus on their health problems is very important in order to provide healthy life to the people in estate sector whose main income totally depend on the working capacity of workers in tea estates and the majority represent tea pluckers. Thus, aim of this study was to assess prevalence of musculoskeletal pain and environmental health hazards among tea pluckers of Maddekanda tea estate in Balangoda Pradeshiya Saba Division, Sri Lanka.

\section{Methodology}

This study was a descriptive cross-sectional study, conducted

Table 1. Socio-demographic characteristics of tea pluckers.

\begin{tabular}{|c|c|c|}
\hline Variable & $\begin{array}{l}\text { Frequency } \\
(\mathrm{n}=378)\end{array}$ & $\%$ \\
\hline $\begin{array}{l}\text { Age } \\
\text { 18-30 years } \\
\text { 31-50 years } \\
\text { 51-60 years } \\
\text { 61-80 years } \\
>80 \text { years }\end{array}$ & $\begin{array}{c}54 \\
195 \\
85 \\
43 \\
1\end{array}$ & $\begin{array}{l}14.3 \\
51.6 \\
22.5 \\
11.4 \\
0.3\end{array}$ \\
\hline $\begin{array}{l}\text { Gender } \\
\text { Female } \\
\text { Male } \\
\end{array}$ & $\begin{array}{l}262 \\
116\end{array}$ & $\begin{array}{l}69.3 \\
30.7\end{array}$ \\
\hline $\begin{array}{l}\text { Civil Status } \\
\text { Married } \\
\text { Unmarried } \\
\text { Divorced }\end{array}$ & $\begin{array}{c}365 \\
19 \\
3\end{array}$ & $\begin{array}{r}94.2 \\
5.0 \\
0.8\end{array}$ \\
\hline $\begin{array}{l}\text { Family type } \\
\text { Nuclear family } \\
\text { Extended family }\end{array}$ & $\begin{array}{l}209 \\
169\end{array}$ & $\begin{array}{l}55.3 \\
44.7\end{array}$ \\
\hline $\begin{array}{l}\text { Ethnicity } \\
\text { Tamil } \\
\text { Sinhala }\end{array}$ & $\begin{array}{l}276 \\
102\end{array}$ & $\begin{array}{l}73.0 \\
27.0\end{array}$ \\
\hline $\begin{array}{l}\text { Educational level } \\
\text { Illiterate } \\
\text { Up to grade } 5 \\
\text { Not complete grade } 5 \\
\text { Not complete grade } 10 \\
\text { Up to O/L } \\
\text { Up to A/L }\end{array}$ & $\begin{array}{c}60 \\
82 \\
67 \\
92 \\
70 \\
6\end{array}$ & $\begin{array}{c}15.9 \\
21.7 \\
17.7 \\
24.3 \\
18.5 \\
1.6\end{array}$ \\
\hline $\begin{array}{l}\text { Monthly income (Rs) } \\
\quad<5000 \\
5000-10000 \\
10001-20000 \\
20001-30000 \\
>30000\end{array}$ & $\begin{array}{c}18 \\
205 \\
107 \\
35 \\
12\end{array}$ & $\begin{array}{c}4.8 \\
54.2 \\
28.3 \\
9.3 \\
3.2\end{array}$ \\
\hline
\end{tabular}

in the Maddekanda tea estate in Balangoda division. Balangoda is situated in the Rathnapura district of the Sabaragamuwa province of the Sri Lanka. All tea pluckers in Maddekanda tea estate in Balangoda division who had working experience more than 1 year whose age above 18 years were included and pregnant mothers were excluded in this study. A total of 384 tea pluckers was included by selecting them through simple random sampling method using the pay rolls of the workers as the sampling frame. Respondent rate was $98.4 \%$.

Data were collected using pretested interviewer administered questionnaire (IAQ). IAQ was validated through judgemental validity of face validity and content validity by occupational experts. All experts did some overall changes especially on the wording and the understanding in the local context. These changes were attended to by the investigator. The IAQ was prepared in English and then was translated to Tamil language by two bilingual English-Tamil experts. They were requested by the principle investigator (PI) to retain the original structure and content as much as possible. The PI discussed some variations with the two experts and consensual alterations were made. The agreed Tamil version of the IAQ was back translated to English by other two bilingual English - Tamil experts. The back translated version was again rechecked with the original version of IAQ by the PI for consistency and accuracy of the information. However, only a few minor discrepancies were found and were corrected again after discussions with the expert translators.

IAQ was pretested among ten (10) tea pluckers who were living in other tea estate of the Balangoda Pradeshiya Saba Division. The modifications were made in the questionnaire by

Table 2. Work characteristics of tea pluckers.

\begin{tabular}{|c|c|c|c|}
\hline $\begin{array}{l}\text { Variable } \\
\quad(\mathrm{n}=378)\end{array}$ & Frequency & $\%$ & Mean \pm SD \\
\hline $\begin{array}{l}\text { Age at started to work as a tea plucker } \\
\leq 20 \text { Years } \\
21 \text { Years }\end{array}$ & $\begin{array}{l}235 \\
143\end{array}$ & $\begin{array}{l}62.2 \\
37.8\end{array}$ & $20.92 \pm 8.631$ \\
\hline $\begin{array}{l}\text { Years of working experience as a tea plu } \\
\leq 10 \text { Years } \\
11-30 \text { Years } \\
\geq 31 \text { Years }\end{array}$ & $\begin{array}{l}\text { lucker } \\
100 \\
154 \\
124\end{array}$ & $\begin{array}{l}26.5 \\
40.7 \\
32.8\end{array}$ & $23.11 \pm 15.02$ \\
\hline $\begin{array}{l}\text { Weight of plucked tea leaves per day } \\
\quad \leq 25 \mathrm{~kg} \\
26-50 \mathrm{~kg} \\
\geq 51 \mathrm{~kg}\end{array}$ & $\begin{array}{c}169 \\
205 \\
04\end{array}$ & $\begin{array}{c}44.7 \\
54.2 \\
1.1\end{array}$ & $30.26 \pm 9.08$ \\
\hline $\begin{array}{l}\text { Weight of carrying tea leaves on your bac } \\
\quad \leq 35 \mathrm{~kg} \\
\geq 36 \mathrm{~kg}\end{array}$ & $\begin{array}{c}\text { ack per day } \\
241 \\
134\end{array}$ & $\begin{array}{l}64.3 \\
35.7 \\
\end{array}$ & $30.82 \pm 14.39$ \\
\hline $\begin{array}{l}\text { Hours of working per day } \\
\quad<8 \text { hours } \\
\quad \geq 8 \text { hours }\end{array}$ & $\begin{array}{l}196 \\
182\end{array}$ & $\begin{array}{l}51.9 \\
48.1\end{array}$ & \\
\hline $\begin{array}{l}\text { Site of hang your basket } \\
\text { On head } \\
\text { On shoulder } \\
\text { On head and on shoulder } \\
\text { On the floor }\end{array}$ & $\begin{array}{c}364 \\
6 \\
6 \\
2\end{array}$ & $\begin{array}{l}96.3 \\
1.6 \\
1.6 \\
0.5\end{array}$ & \\
\hline $\begin{array}{l}\text { Transport mode of plucked tea leaves } \\
\text { On head } \\
\text { On shoulders } \\
\text { On back } \\
\text { On head and shoulder } \\
\text { On head and back } \\
\text { Not carrying weight } \\
\end{array}$ & $\begin{array}{c}294 \\
67 \\
3 \\
4 \\
4 \\
5\end{array}$ & $\begin{array}{l}77.8 \\
17.7 \\
0.8 \\
1.1 \\
0.3 \\
1.3\end{array}$ & \\
\hline
\end{tabular}


improving the clarification of questions, dropping some questions and changing some words from technical terms to local language based on the pre-testing.

In addition, Anthropometric measures were also obtained from study participants using standard measurements. Data were collected by trained data collectors who were fluent in the mother tongue (Tamil language) of the participants. Accuracy, reliability and specially honesty were stressed to the data collectors.

Data analysis was carried out using statistical package for social science SPSS (version 20) and descriptive statistics was used to estimate the prevalence of health problems and chi-square test was used to determine the associations between two categorical variables. Chi square and unadjusted odds ratio with their $95 \%$ confidence interval $(95 \% \mathrm{CI})$ test was used to check the significance of the differences observed. A probability level of $p<0.05$ was accepted as statistical significance. Ethical approval for the study was obtained from the Ethics Review Committee, Faculty of Medical Sciences, University of Sri Jayewardenepura.

\section{Results}

\section{Socio-demographic characteristics of the participants}

Among all participants, only 378 were responded and respondent rate was $98.4 \%$. More than half (52\%) of participants were within the age range of 31-50 years with the mean age of 44.75 $( \pm 13.07)$ years. Majority $(69 \%)$ of tea pluckers were female and were married (94.2\%). Only very few $(1.6 \%)$ participants had followed advanced level and nearly $54 \%$ of them had the monthly income of Sri Lanka Rs 5000-10000 (Table 1).

\section{Working characteristics of the participants}

The mean years of working experience was $23.92( \pm 15.02)$ years. Nearly $62 \%$ of the participants had started to work as a tea plucker before age of 20 years. Around half (54\%) of them usually pluck more than 25 kilograms of tea leaves per day. All participants had used nylon bag and majority of them had kept their Nylon bag on the head to put plucked tea leaves. Nearly $78 \%$ of them carry plucked tea leaves to the collecting center on their head (Table 2).

Table 3. Participants' habits of substance usage.

\begin{tabular}{|c|c|c|c|c|c|c|}
\hline & \multicolumn{2}{|c|}{ Total $(\mathrm{n}=378)$} & \multicolumn{2}{|c|}{ Female $(\mathrm{n}=262)$} & \multicolumn{2}{|c|}{ Male $(\mathrm{n}=116)$} \\
\hline & n & $\%$ & $\mathrm{n}$ & $\%$ & n & $\%$ \\
\hline \multicolumn{7}{|l|}{ Betel chewing } \\
\hline Yes & 233 & 61.6 & 142 & 54.2 & 91 & 78.4 \\
\hline No & 145 & 38.4 & 120 & 45.8 & 25 & 21.6 \\
\hline \multicolumn{7}{|l|}{ Usage of alcohol } \\
\hline Yes & 97 & 25.7 & 6 & 2.3 & 91 & 78.4 \\
\hline No & & 281 & 74.3 & 256 & 97.7 & $25 \quad 21.6$ \\
\hline Years of alcohol usage & & Frequency & & $\%$ & & \\
\hline$<5$ & & 17 & & 17.5 & & \\
\hline $5-10$ & & 13 & & 13.4 & & \\
\hline 10.1- 20 & & 28 & & 28.9 & & \\
\hline$>20$ & & 39 & & 40.2 & & \\
\hline \multicolumn{7}{|l|}{ Type of liquor } \\
\hline Local & & 9 & & 9.3 & & \\
\hline Branded & & 85 & & 87.6 & & \\
\hline Both type & & 3 & & 3.1 & & \\
\hline \multirow[t]{2}{*}{ Currently smoking } & & Total $(\mathrm{n}=378)$ & & ale $(n=262)$ & & Male $(n=116)$ \\
\hline & n & $\%$ & n & $\%$ & n & $\%$ \\
\hline Yes & 49 & 13.0 & 2 & 0.8 & 47 & 40.5 \\
\hline No & 329 & 87.0 & 260 & 99.2 & 69 & 59.5 \\
\hline Years of smoking & & Frequency & & $\%$ & & \\
\hline$<5$ & & 5 & & 10.2 & & \\
\hline $5-10$ & & 9 & & 18.4 & & \\
\hline $10.1-20$ & & 11 & & 22.4 & & \\
\hline$>20$ & & 24 & & 49.0 & & \\
\hline \multicolumn{7}{|l|}{ Type of smoking } \\
\hline Cigarettes & & 14 & & 28.6 & & \\
\hline Biddies & & 34 & & 69.4 & & \\
\hline Cigarettes \& biddies & & 1 & & 2.0 & & \\
\hline \multicolumn{7}{|c|}{ Number of cigarettes /biddies per day } \\
\hline $5 /$ day & & 37 & & 75.5 & & \\
\hline 6-10/day & & 9 & & 18.4 & & \\
\hline 11-20/ay & & 2 & & 4.1 & & \\
\hline$>21 /$ day & & 1 & & 2.0 & & \\
\hline
\end{tabular}




\section{Participants' habits of substance usage}

Nearly $62 \%$ of participants had the habits of betel chewing and among them, males were dominant $(78.4 \%)$ in betel chewing. Nearly one fourth of participants do consume alcohol regularly and among them $40 \%$ of them had consumed alcohol more than 20 years. Further, only $13 \%$ of participants smoke regularly (Table 3 ).

\section{Prevalence of musculoskeletal pain}

The prevalence of musculoskeletal pain in any region of the body was 68.5\% (95\% CI 63.6-73.2) among all participants (Table 4).

\section{Prevalence of environmental health hazard}

Leech biting (98\%) was the most common work hazard among workers during working hours. Around $38 \%$ of tea pluckers had experienced with cut injuries and punch from sharp wood (especially, sharp tea branches) was nearly $26 \%$ during working hours (Table 5).

\section{Factors associated with musculoskeletal pain among tea pluckers}

Participants who had experienced stress were nearly 2 times more likely to have musculoskeletal pain than participants who had no stress (OR=1.974, 95\% CI: 1.149-3.393). Further, participants who worked for more than 20 years $(\mathrm{OR}=2.225,95 \% \mathrm{CI}$ : 1.421-3.485) and aged more than 50 years $(\mathrm{OR}=1.767,95 \% \mathrm{CI}$ : $1.138-2.745)$ were nearly 2 times more likely to have musculoskeletal pain when compared to their counterparts (Table 6).

\section{Discussion}

This study assessed the prevalence of musculoskeletal pain and environmental health hazards among tea pluckers of Maddekanda tea estate in Balangoda Pradeshiya Saba Division, Sri Lanka. Majority of tea pluckers were married which is consistnt with a Sri
Lankan carried out in agriculture sector. ${ }^{9}$

Majority of workers had more than 10 years' experience as a tea plucker. Similarly, agricultural studies also have shown that majority of workers had 10-30-years' experience. ${ }^{10,11]}$ Mean weight of plucked tea leaves per day was $30.26 \mathrm{~kg}$ and most of them plucked more than $25 \mathrm{~kg}$ per day. This finding was consistant with

Table 4. Musculoskeletal pain among tea pluckers.

\begin{tabular}{lcc} 
Type of pain & Frequency $(\mathrm{n}=378)$ & Prevalence $(95 \% \mathrm{CI})$ \\
Any musculoskeletal pain & 259 & $68.5(63.6-73.2)$ \\
Neck pain & 85 & $22.5(18.4-27.0)$ \\
\hline Shoulder pain & 97 & $25.7(21.3-30.4)$ \\
Hand/arm pain & 88 & $23.3(19.1-27.9)$ \\
\hline Upper back pain & 113 & $29.9(25.3-34.8)$ \\
Low back pain & 164 & $43.4(38.3-48.8)$ \\
\hline Knee pain & 158 & $41.8(36.8-47.0)$ \\
Ankle pain & 33 & $8.7(6.1-12.0)$ \\
\hline
\end{tabular}

Table 5. Other occupational hazards experienced by the participants.

\begin{tabular}{lcc} 
Variable & Frequency $(\mathrm{n}=378)$ & $\%$ \\
Honeybee or wasp attack & 93 & 24.6 \\
Snake bite & 53 & 14.0 \\
\hline Fallen from height & 73 & 19.3 \\
Cut injuries & 145 & 38.4 \\
\hline Punch from sharped wood & 99 & 26.2 \\
Injuries to head & 19 & 5.0 \\
\hline Muscle sprain & 97 & 25.7 \\
Experience of leech bite (very often) & 372 & 98.4 \\
\hline Non-healing wound & 22 & 5.8 \\
\hline
\end{tabular}

Table 6. Factors associated with any musculoskeletal pain

\begin{tabular}{|c|c|c|c|c|c|c|c|c|}
\hline & Yes & No & $\begin{array}{r}\text { Any } \\
\text { p-value }\end{array}$ & $\begin{array}{l}\text { of mu } \\
\text { OR }\end{array}$ & $\begin{array}{l}\text { uloskeletal pain } \\
95 \% \text { CI }\end{array}$ & p-value & AOR & $95 \%$ CI \\
\hline $\begin{array}{l}\text { Stress } \\
\text { Yes } \\
\text { No }\end{array}$ & $\begin{array}{c}77 \\
182\end{array}$ & $\begin{array}{l}21 \\
98\end{array}$ & $0.013^{*}$ & 1.974 & $1.149-3.393$ & 0.010 & 2.121 & $1.196-3.764$ \\
\hline $\begin{array}{c}\text { Duration of work } \\
>20 \text { years } \\
\leq 20 \text { years } \\
\end{array}$ & $\begin{array}{l}142 \\
117\end{array}$ & $\begin{array}{l}42 \\
77\end{array}$ & $0.001^{*}$ & 2.225 & $1.421-3.485$ & 0.002 & 2.281 & $1.366-3.809$ \\
\hline $\begin{array}{l}\text { Age } \\
\begin{array}{l}>50 \text { years } \\
\leq 50 \text { years }\end{array}\end{array}$ & $\begin{array}{l}141 \\
118\end{array}$ & $\begin{array}{l}48 \\
71\end{array}$ & $0.011^{*}$ & 1.767 & $1.138-2.745$ & 0.048 & 1.027 & $1.000-1.055$ \\
\hline $\begin{array}{l}\text { Support from supervisor } \\
\text { Yes } \\
\text { No }\end{array}$ & $\begin{array}{c}52 \\
207\end{array}$ & $\begin{array}{c}15 \\
104\end{array}$ & 0.077 & 1.742 & $0.936-3.240$ & 0.192 & 1.540 & $0.805-2.945$ \\
\hline $\begin{array}{l}\text { Age at started to work } \\
\quad \leq 20 \text { years } \\
\geq 21 \text { years }\end{array}$ & $\begin{array}{l}165 \\
94\end{array}$ & $\begin{array}{l}70 \\
49\end{array}$ & 0.363 & 1.229 & $0.788-1.916$ & 0.925 & 0.975 & $0.572-2.945$ \\
\hline $\begin{array}{l}\text { Hours of work per day } \\
\quad \geq 8 \text { hours } \\
<8 \text { hours }\end{array}$ & $\begin{array}{l}117 \\
142\end{array}$ & $\begin{array}{l}65 \\
54\end{array}$ & 0.088 & 0.685 & 0.443-1.059 & 0.152 & 1.419 & $0.879-2.293$ \\
\hline
\end{tabular}

*Chi-square test; OR, odd ratio; AOR, adjusted odd ratio. 
a Kenyan study. ${ }^{12}$ Further, majority of tea pluckers used Nylone bag for collecting tea leaves and hanging the bag on their head. Bhattacharyya and Chakrabarti have written in their study that the newly designed plucking basket fits to back curvature of the workers well and it is better than exsisting round basket. ${ }^{13}$ But, none of them used cane basket or any other basket other than nylone bags in the present study. This might be due to the difference between plucking operations of tea pluckers in Sri Lanka and Assam in India.

Alcohol consumption among tea pluckers was slightly higher among both gender of tea pluckers. Similarly, an epidemiological study carried out among female tea pluckers in Nuwara Eliya district, Sri Lanka revealed that one third of estate women consume alcohol. ${ }^{14}$ This might be due to the cold climate of the place and workers are used to consume alcohol in a regular basis.

The results of this study have shown that musculoskeletal pain (MSP) was most common health problem among the participants and majority $(68.5 \%)$ of workers suffered from at least one of MSP. Similarly, a recent study conducted among rubber trappers in Sri Lanka, found that nearly $66 \%$ of workers had MSP. ${ }^{10}$ In addition, the prevalence of any MSD among oil palm plantation workers in Malaysia was $93 \%{ }^{15}$ and pineapple plantation workers in Johor was around $87.0 \% .{ }^{11}$ Prevalence of MSP was high among tea pluckers might be due to the increased physical activities, long time standing, walking long distance, hard-working compared to other occupational population so on.

Nearly half of the study participants have experienced pain on lower back, followed by knee upper back and shoulder. The similar finding was reported in a Kenyan study that prevalence of lower back pain (LBP) among tea pickers was $45.4 \%{ }^{12}$ and a study done among tea pluckers in India has found that prevalence of LBP was around $47.2 \% .{ }^{16}$ In addition, It was similar with prevalence of LBP among rubber trappers in Sri Lanka $(43 \%)^{10}$ too though job tasks of rubber trappers are quite different from tea pluckers. But, contrast to this findings, LBP among Pineapple plantation workers was high (64.8\%). ${ }^{11}$ MSP among tea plukers were high, this can be justified that most of time workers have to climb mountain while working where Maddekanda tea estate of Balangoda area which is situated in hill areas due to geogrpical situation.

According to current study, most of MSPs are associated with years of working duration, stress level and age of the workers. Similarly, a study by Warnakulasuriya et al. reported that pain was strongly associated with psycho-socioal factors in working poulations ${ }^{17}$ and also age and work experince have postive correlations and people who are more towards old age more prone to get musculoskelital pains. Further, previous studies reported that the MSP is asociated with duration of employment and age of the workers. ${ }^{9,12}$

Limitation of the study was that the study was confined and conducted to one study area.

\section{Conclusions}

Prevalence of musculoskeletal disorders were high among tea pluckers. Lower back region was the common site of pain followed by knee pain. Leech bite was the other dominant health hazard faced by them. Stress, working duration and age were determinant of musculoskeletal pain. Actions should be taken to minimize the risk factors associated with occupational health problem in order to minimize the musculoskeletal pain among tea pluckers.
Correspondence: Dr. SSP Warnakulasuriya, Dean Faculty of Nursing, University of Colombo, Sri Lanka. Tel. +94.715406688.

E-mail: sudath@den.cmb.ac.lk

Key words: Occupational health problems; musculoskeletal pain; tea pluckers; Sri Lanka.

Contributions: UHSC and SSPW have designed the study, collected, analyzed, and interpreted the data; GK has interpreted the data and wrote the manuscript. All the authors have read and approved the final version of the manuscript and agreed to be accountable for all aspects of the work.

Acknowledgements: The Authors would like to convey their gratitude to all participants who spent their valuable time to participate in this study despite their busy work schedule. Also, we would like to thank all staff members in Maddekanda tea estate for allowing to conduct the study in their workplace and their moral support during data collection.

Conflict of interest: The authors declare that they have no competing interests, and all authors confirm accuracy.

Ethics approval and consent to participate: Ethical approval for the study was obtained from the Ethics Review Committee, Faculty of Medical Sciences, University of Sri Jayewardenepura, Gangodawila, Sri Lanka. Participants' written informed consent was obtained before the commencement of the study

Availability of data and materials: The data used to support the findings of this study are available from the corresponding author upon request.

Received for publication: 27 May 2020.

Accepted for publication: 15 September 2020.

oCopyright: the Author(s), 2020

Licensee PAGEPress, Italy

Journal of Public Health Research 2020;9:1796

doi:10.4081/jphr.2020.1796

This work is licensed under a Creative Commons Attribution NonCommercial 4.0 License (CC BY-NC 4.0).

\section{References}

1. Keerthisinghe LI. The golden valley of Ceylon tea. Ministry of Foreign Relations, Sri Lanka 2014. Accessed on: 22 Aug 2019. Available from: https://www.mfa.gov.lk/tam/the-golden-valley-of-ceylon-tea/

2. Trevisanato SI, Kim Y. Tea and health. Nutr Rev 2000;8:1-10.

3. Ilyas AH. Estate Tamils of Sri Lanka - a socio economic review. Int J Sociol Anthropol Rev 2014;6:184-91. doi: 10.5897/IJSA12.061

4. Selvaratnam RR, Silva LDR, Pathmeswaran A, Silva NR. Nutritional status and productivity of Sri Lankan tea pluckers. Ceylon Med J 2003;48:114-8. doi: 10.4038/cmj.v49i3.3256

5. WHO. Occupational safety and health. 1950. Available from: http://www.agius.com/hew/resource/ohsilo.htm\#: :text=DEFI NITION\%3A,and\%20people\%20to\%20their\%20jobs

6. Park K. Park's textbook of preventive and social medicine. Jabalpur: Banarsjdas Bhanot Publishers; 2015. p. 606-621.

7. Dihingia PC, Dewangan KN. Musculoskeletal symptoms among tea pluckers in India. Occup Ergon 2012;10:69-81. doi: 


\subsection{3/OER-2012-0193}

8. Tuzun EH. Quality of life in chronic musculoskeletal pain. Best Pract Res Clin Rheumatol 2007;21:567-9.

9. Vasanth D, Ramesh N, Fathima FN, et al. Prevalence, pattern, and factors associated with work related musculoskeletal disorders among pluckers in a tea plantation in Tamil Nadu. Indian J Occup Environ Med 2015;19:167-70. doi: 10.4103/ 0019-5278.173992

10. Stankevitz K, Schoenfisch A, Silva V, et al. Prevalence and risk factors of musculoskeletal disorders among Sri Lankan rubber tappers. Int J Occup Environ Health 2016;22:91-8. doi: 10.1080/10773525.2016.1168073

11. Rani NH, Abidin EZ, Ya'acob NF, et al. Musculoskeletal symptoms risk factors and postural risk analysis of pineapple plantation workers in Johor. J Occup Safety Health 2016;13:17-26.

12. Langat CK, Bii C, Opondo E, Mbakaya CF. Occupational risk factors of low back pain among tea pickers and non-tea pickers in James Finlay (K) Ltd, Kericho County, Kenya. J Biol Agric Healthcare 2015;5:26491.
13. bhattacharyya N, Chakrabarti D. Ergonomic basket design to reduce cumulative trauma disorders in tea leaf plucking operation. Work 2012;41:1234-8. doi: 10.3233/WOR-2012-03081234

14. Weerakoon AP, Jha RK, Wijeweera PR, et al. An epidemiological study on pattern of smoking, alcohol and other drugs consumption among female tea pluckers in Nuwara-Eliya District, Sri Lanka. SAARC J Tubercul Lung Dis HIV/AIDS 2009;6:31-8.

15. Ng YG, Bahri, S, Tamrin M, et al. The prevalence of musculoskeletal disorder and association with productivity loss: A preliminary study among labour intensive manual harvesting activities in oil palm plantation. Industrial Health 2014;52:78-85.

16. Warnakulasuriya SSP, Peiris-John R, Sivayogan S, et al. Workrelated musculoskeletal disorders among mail sorting officers in Sri Lanka: a cross sectional study. J Coll Commun Physic Sri Lanka 2012;17:43-50. doi: 10.4038/jccpsl.v17i1.4933 